\title{
LINGUISTICS
}

UDC 81'373.45

DOI: $10.17223 / 24109266 / 11 / 1$

\section{ON THE FORMATION OF SKILLS OF SPEECH \\ AT THE RESEARCH AND PRACTICAL CONFERENCE \\ IN FOREIGN (ENGLISH) LANGUAGE ON THE PROFESSIONAL \\ SUBJECT OF BACHELORS AND MASTERS \\ OF NON-LANGUAGE UNIVERSITIES}

\author{
L.V. Artamonova, A.A. Pichugina, A.A. Khakimova, T.V. Shilova
}

\begin{abstract}
At the Institute of applied mathematics and computer science of National research Tomsk state university, annually for twenty years a scientific and practical student conference is held. The main purpose of this conference is to provide an opportunity for future specialists to implement the skills and abilities of practical language skills in situations of foreign language professional and scientific communication, namely to make reports in a foreign language, to discuss topics related to the scientific work of the conference participants. Teachers of the department of the English language of natural science and physics and mathematics faculties take an active part in organizing the conference; prepare bachelors and masters for presentation with reports in English. The article considers the method of training bachelors and masters to speak with their project in English at a research and practical conference in a non-language university and the role of the English language teacher in the developing of skills of speech at the conference at each stage of preparation. Many years method of preparing students to speak at a research and practical conference in a foreign language (English) at this Institute shows positive results. Students adequately present their scientific reports, showing a confident knowledge of English as a means of professional communication, thereby increasing the motivation for further improvement of English language for professional purposes.
\end{abstract}

Keywords: British non-language universities, a research and practical conference, speaking skills, professional and scientific communication, presentation.

\section{Introduction}

The preparation of bachelors and masters for research activities is reflected in the Russian Federal educational standards (RFES) and is an obligatory part of the model of a specialist in higher professional education. In this regard, research activity is becoming increasingly important and is becoming one of the main components of professional training for the future specialist.

In our opinion, a scientific and practical conference where students take the first steps towards discoveries and research plays a huge role in their 
research activities and as a consequence is an important part of the educational process. For this reason, special attention is paid to the training of students for the speech performance.

The conference is a form of organization of scientific activity, in which researchers present and discuss their work. Conferences have a number of advantages in comparison with traditional seminars and trainings. The most important of which is that the presentation of participants on similar topics allows consideration of the issue from several sides; the one-sidedness inherent in teaching by one teacher disappears. The conferences facilitates hearing about different approaches to solving one problem [1].

At present, due to the new requirements of the RFES in the training of specialists, it has become traditional to conduct research and practical student's conferences in non-language universities.

The research and practical conference has become a conference where knowledge and experience are exchanged for various kinds of practical and applied tasks, and a conference organized and conducted in a foreign language at a non-language university allowings you to implement and improve the skills and abilities of practical language proficiency in situations of foreign professional and scientific communication [2].

In modern conditions, teaching professional English is an important task, especially in the field of training bachelors and masters of technical departments. Today, many companies and even state enterprises require of their specialists to know a foreign language, since both their import and export activities are often connected with foreign partners, as well as realities of modern education requiring cooperation with foreign universities [3].

The purpose of teaching foreign languages in non-language universities is to achieve a level sufficient for the practical use of foreign language in future professional activities.

\section{Stages of preparation of bachelors and masters to make a speech at the conference}

At the Institute of applied mathematics and computer science of National Research Tomsk State University, annually for twenty years a scientific and practical student conference has been held. Teachers of the department of the English language of natural science and physics and mathematics faculties take an active part in organizing the conference; prepare bachelors and masters for presentation with reports in English, knowledge of which for the future specialist is a necessary component in the development of a fully developed personality.

The main purpose of the scientific conference is to provide an opportunity for future specialists to implement the skills and abilities of practical language skills in situations of foreign language professional and scientific 
communication, namely to make reports in a foreign language, to discuss topics related to the scientific work of the conference participants. Speakers' presentations on research in the professional field of students are presented in foreign (English) language and accompanied by a demonstration of presentations in PowerPoint format. The time allocated for each report is no more than 10 minutes. Very important, in our opinion, is the period of discussion of the report, since it is at this stage that students demonstrate the ability to conduct a dialogue in a foreign language on professional topics.

To participate in the conference, which is held regularly in spring, bachelors and masters under the guidance of teachers begin to prepare from the start of the school year. The ground work and research work take place in several stages, which we will consider, emphasizing the role of the English teacher in each.

Considering the stages of formation of skills of speech at the research and practical conference of bachelors and masters, it should be noted that the preparation of bachelors of the 3rd year to the presentation of the report is different from that of masters, due to different goals, objectives and content of training programs depending on the qualification of the graduate in the relevant areas. If students of the third year of study, mastering the variable (obligatory) part of the basic educational curriculum (BEC) of the bachelor's degree in foreign (English) language, after having passed the basic course, only start to study the professionally oriented language, the master students already have the opportunity to further develop and improve professionally oriented foreign-language communicative competence for solving academic and research problems, as well as for implementation of intercultural vocational guidance communication with representatives of the scientific world. Taking this into account, it is necessary to differentiate work in the stages of preparation for a speech at the conference.

First stage is the collection of information on the chosen research topic with the academic advisor. At this stage, we mean a large amount of independent work of a bachelor or a master's degree student who are engaged in search for authentic materials on the chosen topic in English, reading them, gaining vocabulary on a given topic (professional terms, clichés, etc.). In the case of bachelors, it is also introduction to professional vocabulary, unlike master degree students who already have experience. Reading scientific articles on a given topic allows bachelors to get acquainted with the most frequently used vocabulary and grammatical structures in their professional field, and their colleagues studying at the next stage, to improve their grammatical competence. This stage is the longest in time: hard work begins long before the conference, six months or more.

The role and work of an English teacher at this stage is great and responsible. It is necessary not only to properly organize the independent work of students (recommend sources of material search, determine the volume 
and level of complexity of texts in accordance with the level of English language proficiency of the student, etc.), but also its control. By exercising control at this stage, the English teacher checks the reading and translation of randomly selected passages from the text, correcting, if necessary, pronunciation and checking the reading comprehension. In addition, the teacher conducts a short conversation on the material read, having listened to the prepared retelling of the text, thereby developing monological speech and the ability to conduct a dialogue, which is extremely important in terms of preparing for the conference.

Second stage - preparation of the report. Having passed the first long stage of information gathering, potential speakers start preparing their report. At this stage, students in the classroom with the teacher get acquainted with the linguistic features of writing a report on scientific activities in the form of a scientific report, as well as a scientific article, which is especially important for novice scientists - masters and postgraduate students, and therefore learning their written scientific speech is given special attention [4]. Work in the classroom is also accompanied by the independent work of the students on the analysis of authentic sample texts. In the classroom and independently, they perform exercises in order to examen means of cohesiveness, to replace synonyms, to analyze the grammatical features of individual parts of the text (for example, the use of modern forms and constructions in the annotation to the article, articles in headings, etc.). In addition, the teacher offers a number of exercises to work with language clichés of scientific style and with special professional terminology, as well as exercises for their consolidation. In addition to the exercises of the lexical and grammatical block, exercises aimed at the development of oral communication skills are used, in which students are invited to analyze, compare, identify shortcomings and improve certain parts of the proposed scientific article or report. For these purposes, it is proposed to perform a number of question-answer exercises and exercises-statements of one's own opinion on the problem. This stage also involves the study of formal requirements for the publication of abstracts and articles and for the presentation of reports at the conference.

The result of the work at this stage is the draft version of the report in English, which should take into account all the rules and requirements for writing a report.

Third stage - correction of the report and preparation for the presentation implies the joint work of the teacher and the speaker. This work can be conducted in the classroom with the participation of other speakers, who, analyzing the report of their colleague, not only help to improve one's report, but also get the opportunity to correct similar mistakes and shortcomings in their own. In addition, this option may be a rehearsal of the performance in front of the public, especially if the student has no such experience. The work of the teacher and speaker at this stage can also be carried out out- 
side the classroom. The report and presentation can be checked and adjusted individually through Internet communications which like other information and communication technologies (ICT), play a major role in teaching a foreign language [5].

Fourth stage - presentation at the conference and its analysis. The main role at this stage belongs to the speakers, but the teacher attending the conference, after listening to the reports, analyzes them and discusses all pros and cons of reports, presentations with students after the conference. The analysis of shortcomings and especially the emphasis on positive points are necessary to increase the motivation for mastering the English language to continue the effective work of students in their professional field of activity.

\section{Conclusion}

Summing up, it should be said that the carefully designed and improved for many years method of preparing students to speak at a research and practical conference in a foreign language (English) at the faculty of computer science of Tomsk state university shows positive results. Students adequately present their scientific reports, showing a confident knowledge of English as a means of professional communication, thereby increasing the motivation for further improvement of English language for professional purposes.

\section{References}

1. Petukhova, G.N.: Student conference as one of the types of independent work // Interactive scientific and methodological journal Community of English Teachers, 4 (2013). URL: http://tea4er.ru/volume4/3244-2013-05-02-15-05-43.

2. Shustikova, T.V.: Student educational and scientific conference as a form of work on the development of communicative competence of foreign students (pre-University stage of education) (2013). URL: http://icee.dis.spbstu.ru/proceedings2012/papers/FSTU/ FSTU2012-17.pdf.

3. Dudina, M.G.: The use of video materials in English lessons // Modern trends in teaching foreign languages and intercultural communication: Materials of the international correspondence research and practical conference. Elektrostal: New humanitarian Institute. p. $46(2011)$

4. Shilova, T.V., Artamonova, L.V., Yevtushenko, T.G.: Optimization of teaching written English scientific speech of students of non-language faculties (based of material of authentic scientific texts) // Pedagogical journal. Vol. 7 (2A). pp. 270-277 (2017)

5. Shilova, T.V., Artamonova, L.V.: E-tests in Moodle system as a means of optimizing the learning process of English to students of physics-mathematical faculties // Izvestiya vuzov. Physics. Vol. 58 (8/3). pp. 321-323 (2015)

\section{Information about the authors:}

Artamonova L.V. - a senior teacher of the department of the English language of natural science and physics and mathematics faculties of National Research Tomsk State University (Tomsk, Russia). E-mail: nastiaart@sibmail.com 
Khakimova A.A. - a senior teacher of the department of the English language of natural science and physics and mathematics faculties of National Research Tomsk State University (Tomsk, Russia). E-mail: alfamir@sibmail.com

Pichugina A.A. - a senior teacher of the Institute of applied mathematics and computer science of National Research Tomsk State University (Tomsk, Russia). E-mail: aapichugina@gmail.com

Shilova T.V. - a senior teacher of the department of the English language of natural science and physics and mathematics faculties of National Research Tomsk State University (Tomsk, Russia).E-mail: tvshilova@hotbox.ru

Received 5 May 2018 